the bare earth, crowded together with hardly walking room between them. Amongst the birds stepped a pretty Sheath-bill (Chionis $a l b a$ ) with a quiet jaunty stride, picking what he could, and apparently perfectly indifferent to the motions of the penguins, who drove at him with their beaks as he passed, but never struck him. I saw him pass and repass one bird always just out of reach, till the bird could stand it no longer, but reached off her nest about an inch to strike him; he was still just out of reach and busy with something, apparently not noticing the penguin; she reached further, he crossed her again, still just out of reach, and tbis went on till he had drawn her about two feet from the nest, then in one stride he was beside the egg, had punched a hole, and was sipping the contents before the slow penguin could turn and hop back to save it; he again led her away by the same mancuvre and increased the hole and got a greater part; a third time he led her off and was eating the egg when be was driven right away by another penguin, who was wandering at liberty, the mate, $I$ suppose, being on turn on the egg. The proceeding on the part of the sheath-bill was a perfect trap for the poor foolish old penguin.

The other instance I will give occurred in the Pacific, where some albatross were circling about, and frequently settling on the water in flocks; some sharks were about, and I watched to see if any albatross would be pulled down; then $I$ noticed a cordon of sentries round the flock, who were relieved at times from the flock, a single bird going out and sitting near the sentry who flew in. Whenever a shark's fin approached the sentry he flew in, and the whole flock took up new position. Here was distinct organisation. The ship was going very slowly through the water, and I was able to study the whole carefully. J. P. MACLEAR

H.M.S. Alert, Straits of Magellan, November 5, 1879

THE following account of an incident in the early life of a South African baboon may not be out of place in your journal The person who witnessed it was a very trustworthy native attached to Bishopstowe, Natal, and who is employed from time to time to get game for the house. He used to find it an agreeable addition to this duty to collect objects of natural history for the cabinet as well as for the table. He was fully alive to, and took a keen interest in, what went on among the animals of all kinds, and was much struck with what he saw take place one day at the bottom of a little iDong $a$, or dry watercourse, over the brink of which he peeped, on the slope of a table-mountain, the grand object that lies in the front of Bishopstowe, some twelve miles distant.

It was a hot day, and a number of baboons were sunning themselves along the bottom of the iDonga. They lay upon their backs, with half-closed eyes, rubbing their stomachs in a state of placid enjoyment. Two or three young baboons had wandered to a little distance down the iDonga, searching for scorpions from stone to stone just below them. They were not very successful, and it did rot appear that their movements were of much concern to their elders. Presently, however, one of the young ones, turning up a stone, lit upon a particularly fine and fat scorpion, which, with a furtive glance round at his elders, he seized and popped into his moutb, having first pinched off the sting. He at once proceeded to turn the stone over again with great assiduity, as though in further unsuccessful search for scorpions. He had not escaped notice, however, for down the gully in a sluggish roll came a great baboon, who seized the young one by the scruff of the neck, shaking him vigorously until the plump morsel dropped from his pouch. Having gobbled this up, the elder baboon at once regained his lounge, and all went on as before in the sleepy hollow.

London, January 8

Francis E. Colenso

Notes on tie Papuans of Maclay Coast, New Guinea

THE articles on the above subject which have appeared in NATURE, vol. xxi. pp. 204, 226, have been read by me with great interest in consequence of the resemblance which certain of the customs therein described have to some which have come under my observation among the inhabitants of the Andaman and Nicobar Islanc's.

With regard to the custom of the relatives of deceased persons in the Andamans ornamenting and carrying about the skulls of the departed, which is alluded to in a note on p. 205 , I believe I may claim to have first described and figured such a skull. My paper entitled "On a Visit to the Andamanese Home, Port Blair, Andaman Islands" (of which I inclose a copy), was pub- lished in the Proceedings of the Royal Irish Academy for $187 \mathbf{I}$. In it I mentioned, together with some other facts, that I had witnessed the process of making flakes from a piece of bottleglass which I saw subsequently employed for shaving.

An Andamanese necklace made of human clavicles and turtles' ribs is now in my possession, and I believe human finger and toe bones are also sometimes strung together and worn round the neck. In reference to the ideograph discovered by $\mathrm{Mr}$. Maciay among the Papuans I would refer to a paper "On Nicobarese Hieroglyphics or Picture Writing," which I communicated to the pages of the Indian Antiquary (Bombay) in the year 1875 .

The screen which is figured is one out of many which I saw in the Nicobar Islands. It consists of the spathe of a palm and is covered with representations, done in vermilion, of me . (in various attitudes), pigs, fish, houses, canoes, weapons, \&c., \&cc. It would take up too much space to give details of it here, tut I may state that my conclusion regarding it was that it was the pictorial record of some past event. Both skull and screen are described, but unfortunately not figured, in my recently-published work, "Jungle Life in India."

To any of your readers who may be specially interested in the matter I shall be happy to forward, on application, copies of the papers above mentioned and photographs of the screen so far as the numbers available for the furpose will go.

37, Nortbumberland Road, Dublin, January 9

\section{The Word "Telegraph"}

THE word "telegraph" appears to have been naturalised in our language at a much earlier date than that given by $\mathrm{Mr}$. Warren de la Rue in his letter in NATURE, vol. xxi. p. 226. There are several references to the apparatus in the Gentleman's Magazine for July, December, I 794, and the next three volumes. At first the word appears in its French form with the final "e," but the sign of its foreign origin soon disappears. Under the date January 28, I796, we find amongst "Domestic Occurrences" a paragraph stating that "a telegraph was this day erected over the Admiralty." This, I think, was removed about thirty years ago. In case your correspondent shonld wish to verify the references in the indexes to the Gentleman's Magazine, I may point out that there are two pages numbered 106 in the volume for January to June, $\mathbf{1 7 9 5}$, and that there is an article at p. 1176 of that for July to December, 1794 , not mentioned in the index.

Watt, in his " Bibliotheca Britannica," gives a still earlier reference to the word in R. H. Gower's " Theory and Practice of Seamanship," but there is no mention of a telegraph in the first edition of that work, published in 1793.

The word occurs many times in Dr. Thos. Young's " Lectures on Natural Philosophy," 1807 , and scme interesting information on the subject may be found in Gregory's "Treatise of Mechanics" (2nd ed), vol. ii. p. 434 (London, 1807), where several sorts of telegraphs are described.

H.M. Patent Office, January 12 Richard B. Prosser

\section{Stags' Horns}

THOUgH, no doubt, as $\mathrm{Mr}_{\text {: }}$ Stokoe suggests, many antlers are picked up and rold to knife-handle makers, or, if they happen to be good ones, used for " making up" deers' heads, yet many, I believe, are really eaten by the deer themselves. I have never myself seen a deer engaged in eating a fallen antler, nor, though I have more than once found cast horns on the hills, did the latter present any appearance of having been gnawed.

All the hill men will tell you, however, that it is a well.known fact that red-deer eat the horns that are shed every year, and the late Sir Thomas Moncreiffe once told me that he watched a hind - a cervine Delilah-gnawing the tips of the tines of the horns of a stag that was lying beside her, and which he afterwards shot. In Blair Castle there is a magnificent stuffed stag"Tilt"-which was reared by the late Duke of Athole, who fed it upon, amongst other things, ground deer-horns. As tame stags often do, "Tilt" became dangerous, and had to be killed when he was eight or nine years old. In size he far surpassed any of the wild red-deer, and had most magnificent antlers. As each year's antlers fell off they were preserved, and form an interesting and instructive series.

Considering how fond cows are of gnawing bones, and also how they will eat any woollen garment they can get at, there does not seem to be anything very remarkable in the fact of red deer consuming shed horns.

Perth, January 2 